\title{
Nutritional regulation of leptin in humans
}

\author{
R.A. Coleman, T.S. Herrmann \\ Department of Nutrition, University of North Carolina at Chapel Hill, Chapel Hill, North Carolina, USA
}

Keywords Leptin, hyperinsulinaemic clamp, hexosamine, circadian, diurnal, fasting, insulin, diet, $o b /$ $o b$

\section{Overview}

Positional cloning of the defective gene in genetically obese $o b / o b$ mice identified leptin as the long-sought hormone that communicates information about adipocyte metabolism to the brain [1]. Supplying leptin to genetically deficient $o b / o b$ mice increases metabolic rate, body temperature and general activity and decreases food intake, body weight and adiposity [1-4]. Additionally, the importance of leptin to reproduction has been highlighted by the lack of sexual maturation in people who are genetically deficient in leptin [5] or the leptin receptor [6]. Although many of leptin's effects are centrally mediated, there is growing evidence that peripheral leptin receptors mediate leptin's proliferative effects on haemopoietic cells [7] and its anti-lipogenic effects on muscle and pancreatic islets $[8,9]$.

Because leptin has a critical role in regulating energy metabolism, adipose stores and body weight, questions have been raised concerning the control of leptin synthesis and secretion and the function of leptin in controlling satiety and food intake. Basal or fasting leptin values are higher in women than men, increase during the course of pregnancy and, in both healthy adults and those with Type II (non-insulindependent) diabetes mellitus, are strongly correlated with per cent body fat or BMI $[10,11]$ and adipose tissue mass [12-15]. Despite these strong correlations, people with similar degrees of adiposity have circu-

Corresponding author: R.A. Coleman, MD, Department of Nutrition, CB\# 7400, University of North Carolina at Chapel Hill, Chapel Hill, NC 27599, USA lating leptin concentrations that vary considerably. Thus, factors other than adipocyte size and fat content must influence leptin production. Further, the regulation of leptin's diurnal pattern of secretion is still to be explained.

In this review we summarize current data, primarily from human studies, that address the nutritional controls on leptin synthesis and secretion and point out fruitful areas for future study. Excellent recent reviews should be consulted for information on the leptin receptor, other aspects of leptin's effects, and the relation of leptin to other hormones that regulate food intake and energy expenditure [16-22].

\section{Leptin regulation by fasting, refeeding and overfeeding}

Fasting and refeeding. During short-term energy restriction, plasma leptin concentrations decrease much more than the amount of weight or adipose tissue lost. For example, lean and obese adults who fasted for 52 to $96 \mathrm{~h}$ lost less than $4 \%$ of body weight but the leptin concentrations decreased 54 to $72 \%$ [23-25]. In careful long-term studies of lean and obese people who were either losing weight or maintaining a defined weight loss, leptin concentrations were lower during the period of loss than the period of weight maintenance at the same body composition [26]. After a 4 day fast followed by an additional 6 days of fasting during which an intravenous infusion of $5 \%$ glucose was given, leptin increased $80 \%$ within the first $24 \mathrm{~h}$, even though glucose provided only $338 \mathrm{kcal} /$ day [25]. Although it is possible that the previous 4 day fast confounded these results [27], taken together, these studies suggest that the serum leptin concentration reflects ongoing triacylglycerol synthesis or glucose uptake by fat cells, rather than actual adipocyte stores, because a large fat mass still exists after short-term fasting. Further, when subjects are 
refed after a 3 day fast, leptin values return to baseline within $12 \mathrm{~h} \mathrm{[24].} \mathrm{Thus,} \mathrm{the} \mathrm{amount} \mathrm{of} \mathrm{energy} \mathrm{in-}$ take and fat store replenishment do not seem to be as critical as the presence of insulin-enhanced glucose metabolism.

Discordant values between weight loss and serum leptin are also observed during energy restriction. When lean adults were restricted for 7 day to $68 \%$ of their daily energy requirements, weight loss averaged $4 \%$ but leptin decreased $36 \%$ [28]. The decrease in leptin during fasting correlated independently with the $22 \%$ decrease in glucose and the rise in beta-hydroxybutyrate, factors that reflect decreased glucose availability and increased lipolysis.

Discrepancies are also apparent in the relation between decreased serum leptin during fasting and changes in $o b$ gene expression. For example, abdominal subcutaneous adipose tissue leptin mRNA did not change after a 6 day fast even though serum leptin had decreased $40 \%$ [29]. A hypocaloric diet for 5 days did not change the leptin mRNA content in abdominal subcutaneous fat despite a loss of $3.7 \%$ of body weight; serum leptin values were not reported [30]. These studies suggest that serum leptin is regulated either by changes in leptin clearance or by post-transcriptional control.

The mechanism by which fasting lowers leptin concentrations is not known. Although serum betahydroxybutyrate increases fivefold over baseline during $60 \mathrm{~h}$ of fasting and is inversely correlated with serum leptin concentrations, there was no association between serum leptin and glucose, insulin or fatty acid concentrations [31]. Further, plasma free fatty acid concentrations themselves do not appear to regulate leptin concentration $[32,33]$.

Overfeeding. When normal adults are overfed for $12 \mathrm{~h}$ at $120 \mathrm{kcal} / \mathrm{kg}$ (55\% fat, $15 \%$ protein, $35 \%$ carbohydrate), glucose increases minimally, the fasting insulin concentration doubles and the increase in nocturnal leptin persists until the following morning instead of declining [34]. Overfeeding normal men enough to achieve a $10 \%$ weight gain and an increase in body fat from 15.8 to $19.4 \%$, was accompanied by a threefold increase in fasting leptin concentrations [34]. Although there was a strong linear correlation between leptin and body fat, there was little correlation with insulin in this study.

In summary, the available data on leptin and $o b$ gene mRNA in humans suggest that serum leptin is regulated by energy availability. This regulation is not immediate, however, and the adaptive response of leptin to energy availability is not mediated entirely through changes in serum insulin, fatty acids or beta-hydroxybutyrate. During energy restriction or fasting, leptin does not reflect actual triacylglycerol stores or adipocyte numbers. Instead, the amount of circulating leptin appears to reflect the presence of energy that is sufficient to promote triacylglycerol synthesis rather than lipolysis.

\section{High fat diets and other nutrients}

High fat diets. Although the positive correlation between body fat and leptin may be partly mediated by insulin concentrations in humans, other factors like diet composition could be important. Studies of diets with changed fat and carbohydrate content have yielded mixed results. Rodents have varying susceptibilities to diet composition depending on the strain investigated. In rat strains that gain weight (OsbornMendel) or are resistant (S5B/P1) to high fat diets, feeding a diet that contains $56 \%$ energy from fat increased serum leptin similarly for both strains within 2 days [35]. Not all rodent strains respond similarly. In $\mathrm{A} / \mathrm{J}$ mice, which are resistant to weight gain on a high fat diet, high fat feeding for 14 weeks increased leptin concentrations tenfold, whereas in C57BL/6J mice, which are prone to diet fat-induced obesity, leptin increased only twofold [36]. Leptin mRNA increased almost fourfold in 1 week in Wistar suckling rats weaned to a high fat diet compared with rats weaned to a high carbohydrate diet even though there were no differences in adipose tissue mass, adipocyte size or number, or serum insulin [37]. In addition to their effects on leptin, high fat diets also upregulate the short form of the leptin receptor 11-fold at the rat blood brain barrier, perhaps altering uptake of leptin into the brain [38].

Human studies have shown no effect of high fat diets on leptin. Fasting serum leptin did not change during 7 days on a diet that contained $60 \%$ of energy as fat, although on an individual basis, the leptin response to the high fat diet appeared to correlate with changes in insulin concentrations [12]. Similarly, diets containing fat at 14,23 , or $31 \%$ of energy and which maintained stable weight, had no effect on leptin in lean or overweight women, suggesting that diet fat content at these concentrations does not regulate leptin [13]. In these studies only morning measurements were made and dietary effects on the diurnal leptin pattern were possibly missed. In a study that did compare the 24-h leptin pattern of subjects who ate isocaloric high or low fat meals, the timing of the nocturnal rise in leptin differed substantially (see below), suggesting that diet composition does change serum leptin but that the change would not be apparent between 0700 and 1000 hours [39].

Fibre and other nutrients. Little information is available on the effect of specific nutrients or fibre on serum leptin. Sucrose and amino acids given over $4 \mathrm{~h}$ did not change leptin concentrations despite increases in serum glucose and insulin concentrations [40]. Hydrolysed guar gum had no effect on postprandial 
glucose, insulin or leptin in obese women eating 800 $\mathrm{kcal} /$ day [41]. Zinc restriction does, however, decrease human leptin concentrations [42].

\section{Appetite and satiety}

Although initially identified as a satiety hormone, it has been more recently hypothesized that leptin functions to prevent starvation and maintain reproductive capacity. Thus, in non-obese people, an increase in serum leptin may signal that energy stores are replete, whereas a decrease in leptin may signal the need for food intake as well as inadequate reserves to support pregnancy.

In fact, there is no evidence in humans that serum leptin influences satiety. Numerous studies have shown that the high leptin concentration in obese people is associated with excess rather than diminished food intake. Further, postprandial plasma leptin concentrations do not correlate with immediate subjective feelings of hunger and are not statistically significantly different between two meals that induce different effects on subjective feelings of hunger [43]. Another negative study reported that postprandial feelings of hunger do not differ statistically significantly between diets that contain either high-glycaemic or low-glycaemic index carbohydrates, even though the high-glycaemic index carbohydrate diet increased postprandial leptin concentrations [44]. These limited data suggest that leptin does not mediate energy intake in humans either in the short term or related specifically to meals.

\section{Regulation of leptin by insulin}

Leptin concentrations appear to be regulated by insulin, although questions remain concerning the insulin dose, the time course and the mechanism of control. In one patient, 6 months after an insulinoma was surgically removed, insulin concentrations decreased from 16.2 to $7.6 \mu \mathrm{g} / \mathrm{l}$, leptin decreased about $50 \%$ and the patient's BMI had only decreased from 31 to 28 [45]. In diabetic pregnancies, placenta leptin mRNA and protein increased threefold to fivefold after the women were treated with insulin [46]. These observations strongly support a role for insulin in long-term regulation of leptin secretion from both adipocytes and placenta.

Several studies have been done using euglycaemic hyperinsulinaemic clamps to determine whether insulin infusions rapidly change serum leptin concentrations. Two problems prevent firm conclusions from being drawn. Firstly, the insulin doses (by definition) have been supraphysiological, and secondly, leptin values have usually been compared with an initial value which does not reflect the diurnal changes that occur in serum leptin concentrations. No statistically significant correlations were found between insulin-stimulated glucose uptake and serum leptin concentration, either before or after a 6 day fast in severely obese women [29]. When the 3-h hyperinsulinaemic clamp study (serum insulin at $1.4 \mathrm{nmol} / \mathrm{l}$ ) was carried out without a preceding fast, serum leptin concentrations did not change; following the 6 day fast, however, serum leptin increased $25 \%$ compared with basal values [29]. These data suggest that the effect of insulin on serum leptin concentrations depends on the patient's previous nutritional state. Hyperinsulinaemia (about 900 pmol/l) increased serum leptin concentrations after $8 \mathrm{~h}$ in a dose-dependent manner in lean men but hyperglycaemia or high-plasma fatty acid concentrations did not affect leptin [33].

Hyperinsulinaemic clamp studies support the idea that insulin regulates leptin synthesis and secretion in humans. Because the high amounts of insulin used have been unphysiological, disagreements have centred on how much insulin is needed and how long a period is required to produce an effect. In lean, obese and obese adults with Type II (non-insulin-dependent) diabetes mellitus given various insulin infusion rates (serum insulin from $0.5-86 \mathrm{nmol} / \mathrm{l}$ ) for $5 \mathrm{~h}$, no change in leptin was observed compared with initial concentrations; with a hyperglycaemic clamp, leptin doubled, however, by $50 \mathrm{~h}$ [47]. In a 4-h euglycaemic hyperinsulinaemic clamp (serum insulin at $\sim 600$ pmol/l), compared with basal concentrations after an overnight fast, leptin increased $25 \%$ in healthy control subjects but was unchanged in patients with Type I (insulin-dependent) diabetes mellitus [48]. Compared with a 9-h saline infusion during which leptin concentrations fell $30 \%$, insulin infusions (serum insulin at $\sim 140 \mathrm{pmol} / \mathrm{l}$ ) prevented the fall, showing a prompt insulin effect (Fig. 1) [49]. Infusions of higher amounts of insulin caused increases in serum leptin compared with the initial concentration, and with higher insulin doses, leptin rose earlier and reached higher concentrations [49]. In non-obese men and women, a euglycaemic hyperinsulinaemic clamp increased leptin 5, 26, and 62\% compared with a control saline infusion during sequential 2-h increasing insulin infusions (serum insulins at 379, 823 , and $2843 \mathrm{pmol} / \mathrm{l}$ ) [50]. With a euglycaemic hyperinsulinaemic clamp (serum insulin at $600 \mathrm{pmol} / \mathrm{l}$ ), leptin did not change compared with basal for up to $2 \mathrm{~h}$ in lean and obese subjects [51]. With a hyperinsulinaemic clamp (serum insulin at $480 \mathrm{pmol} / \mathrm{l}$ ), leptin rose $37 \%$ at $6 \mathrm{~h}$ compared with a control saline infusion [52].

Interpretation of these studies has varied. The normal 24-h leptin pattern shows a fall of about $20 \%$ between 0800 and 1200 hours and then a plateau (Fig. 1, curve A). Since the insulin infusions were initiated after an overnight fast, leptin concentrations that re- 


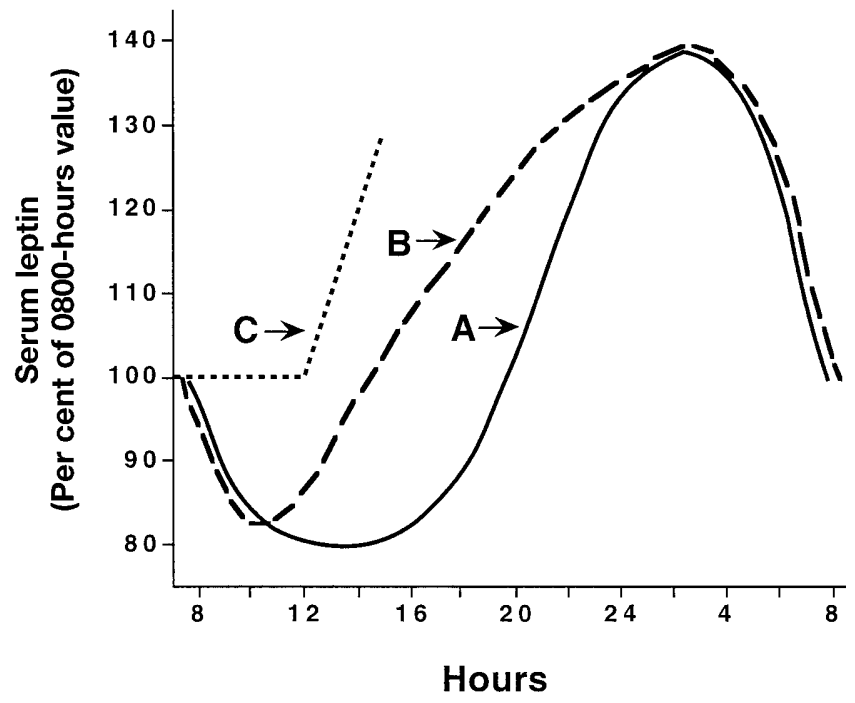

Fig. 1. Plasma leptin during $24 \mathrm{~h}$. Idealized curves are plotted as per cent of the 0800 hours value. Curve A shows the normal curve reported for adults $[39,44,68]$. Curve B shows the curve observed with 3 isocaloric meals of $60 \%$ carbohydrate, $20 \%$ fat [39] or with a diet that contains 55-65\% high glycaemic-index carbohydrate [44]. Curve $\mathrm{C}$ shows leptin values during a typical euglycaemic hyperinsulinaemic clamp

main stable compared with the initial value suggest that hyperinsulinaemia does indeed have an immediate effect, even though an actual rise in leptin concentration is not observed until $6 \mathrm{~h}$ after the start of the infusion (Fig.1, curve C). A major problem is the choice of the control comparison group. It is well established that fasting will lower leptin concentrations and a saline infusion merely continues the overnight fast during which the subjects' endogenously produced insulin decreases and counter-regulatory hormones rise. Another option might be to have the comparison group eat normal meals at 0800 and 1200 hours or to select foods that do not increase endogenous serum insulin.

It must also be kept in mind that changes in serum concentrations of leptin depend on both leptin's rate of synthesis and secretion and on its rate of degradation. Adults with chronic renal failure have leptin values that are threefold higher than healthy subjects' who have a similar BMI [53] and in children with chronic renal failure, inappropriately raised leptin concentrations correlate with the declining glomerular filtration rate [54]. Although the kidney is believed to be important in leptin removal and reduced renal clearance was suspected, leptin concentrations in end-stage renal disease do not correlate well with residual renal function [55]. Decreases in leptin values, including the normal morning decline, might result from changes in renal clearance, and stabilization of morning leptin concentrations by insulin could result from effects on the kidney rather than on adipocyte synthesis.
Insulin effects on human adipocytes and adipose tissue. Although hyperinsulinaemia increases serum leptin at $6 \mathrm{~h}$, the responding adipocyte mRNA abundance has not been well studied. After a 3-h euglycaemic hyperinsulinaemic clamp (serum insulin at $\sim 850 \mathrm{pmol} / \mathrm{l}$ ) adipose glucose transporter 4 (GLUT4) mRNA increased threefold but leptin mRNA did not change [30]. Although serum leptin was not measured in this study, 4-6 h of hyperinsulinaemia are usually required to increase serum leptin concentrations.

In studies of isolated human adipocytes, long exposures to insulin are required before leptin mRNA increases. Abdominal adipocytes exposed directly to $100 \mathrm{nmol} / \mathrm{l}$ insulin did not increase leptin mRNA and release until $72 \mathrm{~h}$ of incubation [47]. In a 48-h incubation of visceral adipose tissue in the presence or absence of insulin (100 nmol/l), leptin mRNA decreased and leptin secretion remained unchanged up to $48 \mathrm{~h}$ although GLUT4 and glycerol-P dehydrogenase mRNA increased [56]. Human preadipocytes contain little leptin mRNA or protein but after differentiation, insulin (1000 pmol/l) increased leptin secretion by $24 \mathrm{~h}$; cortisol increased the effect of insulin about threefold [57]. This effect was reversed when the hormones were removed.

Interpretation of these results would be aided by more information about the cellular and molecular biology of leptin. What is the relation between leptin mRNA abundance and the amount of leptin secreted? Does the relatively stable mRNA expression in adipocytes indicate translational control? Is leptin stored in adipocytes and secreted only after a stimulus or is it secreted as soon as it is synthesized?

The mechanism by which insulin exerts its effects on leptin mRNA expression and protein secretion is not known but probably involves enhanced glucose uptake and metabolism [58]. Insulin increases leptin secretion by rat adipocytes when glucose is present but not in the presence of 2-deoxy-D-glucose unless high concentrations of glucose are added [59]. The same study showed that drugs that inhibit glycolysis or glucose transport also inhibit insulin-dependent leptin secretion and decrease the leptin mRNA content of the adipocytes. It has been proposed that the hexosamine pathway and its final product, UDP-Nacetylglucosamine, mediate leptin's response to glucose. Glucosamine, which enters the hexosamine pathway after the rate-limiting step, induces expression of leptin mRNA in 3T3-L1 preadipocytes and even L6 myocytes [60]. Infusions of glucose or a lipid emulsion for 3-h increased leptin mRNA and UDP$\mathrm{N}$-acetylglucosamine concentrations in fat and skeletal muscle, providing additional links between diet and leptin synthesis [60]. The hexosamine hypothesis is an exciting one but requires further studies in light of the finding that glucosamine also depletes cellular ATP concentrations [61]. 
Leptin's feedback regulation of insulin. A feedback loop possibly exists between leptin and insulin. In perfused rat pancreas, isolated mouse islets [62], and human islets [63], leptin inhibits glucose-induced insulin secretion. Inhibition in human islets, however, required $20 \mathrm{mmol} / \mathrm{l}$ glucose; no effect was observed with concentrations of glucose of $10 \mathrm{mmol} / \mathrm{l}$ or lower $[63,64]$. As would be expected, leptin blocked insulin secretion by islets from $o b / o b$ mice but not by $d b / d b$ mice which lack the leptin receptor [65]. These effects may be mediated by the ATP-sensitive potassium channel $[66,67]$.

\section{Leptin diurnal rhythm and pulsatility}

Leptin's diurnal rhythm was first described in lean, obese, and obese Type II diabetic subjects who had $50-75 \%$ changes in the amplitude of leptin concentrations with nadirs between 1100 and 2000 hours and peaks between 2400 and 0400 hours [68]. This general pattern has been confirmed in adolescent girls [69], young men [33] and lean [70] and obese [71] adults. Some reports describe earlier nadirs at 0900 hours $[72,73]$, although the overall pattern is similar (Fig. 1, curve A). The diurnal pattern is preserved in growth-hormone deficient hypopituitary adults [74] but reduced or absent in patients with anorexia nervosa $[73,75]$ and is absent in amenorrheic athletes [72].

In addition to its diurnal pattern, leptin is also secreted in pulses. In lean, obese and obese Type II diabetic subjects pulsatile secretions had means of approximately 3.5 ultradian oscillations/24 h $[70,76]$. The relative amplitude had no apparent relation to obesity and more frequent sampling of an obese subset showed 2-5 oscillations/12 h [77].

It is not known whether the diurnal leptin rhythm has a function in weight control or energy balance. Leptin is also highest at night in rodents but unlike the human peak which occurs during the overnight fast, the peak in animals occurs when they are feeding [78]. Of interest in this regard is the finding that in lean suckling rats that were fed identical amounts of milk by an artificial rearing technique, recombinant leptin reduced weight gain by increasing energy expenditure, particularly in the morning when pups usually enter a torpor-like state [79]. The authors suggest that the torpor effect is normal and independent of leptin's effects on food intake. If the diurnal rhythm had a similar function in humans, it might be expected that an abbreviated leptin nadir would increase energy use.

The mechanism that underlies the control of leptin's diurnal rhythm is not known. The inherent rhythm is entrained by day/night reversal but when meals were shifted $6.5 \mathrm{~h}$, leptin's peak and nadir also shifted 6-7 h [80]. In the same study cortisol shifted minimally, indicating both a lack of true circadian control and of regulation by glucocorticoids. In two studies which changed diet composition, the 24-h leptin pattern showed an abbreviated nadir and a premature rise, although the absolute peak values at 0200 hours were not affected (Fig.1, curve B) [39, 44]. In one of these reports, lean women were fed iso-caloric meals that contained either $60 \%$ carbohydrate and $20 \%$ fat or $60 \%$ fat and $20 \%$ carbohydrate at 0900,1300 and 1800 hours [39]. Each of the high carbohydrate meals was followed by large increases in serum concentrations of glucose and insulin, and leptin concentrations rose above the 0800 hours baseline by 1300 , so that the 24 -h area under the curve for leptin was $38 \%$ higher. In the second study, lean men and women were examined in a cross-over design with four different diets, each consumed for 8 days [44]. The principal difference in the diets was the presence of either high-glycaemic or low-glycaemic index carbohydrate. In contrast to the first study, glucose and insulin values measured on the eighth day were virtually identical after meals for all four diets. For the diets that contained high-glycaemic index carbohydrates, however, leptin values began their diurnal increase prematurely at 1300 hours, and the leptin AUC was $17 \%$ higher. These studies suggest three important conclusions: that insulin probably changes the timing of the 24-h leptin pattern, that one or more factors unrelated to insulin is also important in this regulation and that single fasting determinations of leptin are likely to be inadequate for nutritional studies.

\section{Summary and future perspectives}

Although leptin was first discussed as an "adipostat" that regulated food intake in accordance with triglyceride stores, it has become clear that leptin's role is much more complex and that a great many unanswered questions persist. Human studies have not shown that serum leptin concentrations can be changed rapidly by meals. Insulin seems to have a modest but immediate effect in attenuating the morning nadir of serum leptin as well as a greater effect manifested after 4-6 h. These changes in serum leptin, like the decreases that occur with fasting, are not accompanied by corresponding changes in adipose leptin mRNA, suggesting regulation by translational control or changes in the rate of leptin degradation, secretion or clearance. There is convincing evidence that insulin increases leptin synthesis and secretion, probably through an insulin-dependent effect on glucose metabolism. This effect of insulin is possibly mediated by the hexosamine pathway. What adipocytes seem to be communicating to the brain is not how much triglyceride they contain but whether they are currently synthesizing or hydrolysing triglyceride. 
Confounding many studies is the problem of leptin's diurnal rhythm. Because many studies only measured leptin during its morning nadir or examined the effects of insulin or specific nutrients provided after an overnight fast, important information on regulation may have been lost.

Acknowledgements. This work was supported in part by grants DK56598 from the National Health Institutes (NIH) and from Mars, Inc.

\section{References}

1. Zhang Y, Proenca R, Maffei M, Barone M, Leopold L, Friedman J (1994) Positional cloning of the mouse obese gene and its human homolog. Nature 372: 425-432

2. Halaas J, Gajiwala KMM, Cohen S, Chait B, Rabinowitz D, Lallone R, Burley S, Friedman JM (1995) Weight-reducing effects of the plasma protein encoded by the obese gene. Science 269: 543-546

3. Campfield L, Smith F, Guisez Y, Devos R, Burn P (1995) Recombinant mouse ob protein: evidence for a peripheral signal linking adiposity and central neural networks. Science 269: $546-548$

4. Pelleymounter M, Cullen M, Baker M, Hecht R, Winters D, Boone T, Collins F (1995) Effects of the obese gene product on body weight regulation in ob/ob mice. Science 269: 540-543

5. Strobel A, Issad T, Camoin L, Ozata M, Strosberg AD (1998) A leptin missense mutation associated with hypogonadism and morbid obesity. Nat Genet 18: 213-215

6. Clement K, Vaisse C, Lahlou N et al. (1998) A mutation in the human leptin receptor gene causes obesity and pituitary dysfunction. Nature 392: 398-401

7. Gainsford T, Wilson TA, Metcalf D et al. (1996) Leptin can induce proliferation, differentiation, and functional activation of hemopoietic cells. Proc Natl Acad Sci USA 93: 14564-14568

8. Muoio DM, Dohm GL, Fiedorek FT, Tapscott EB, Coleman RA (1997) Leptin alters lipid partitioning in skeletal muscle. Diabetes 46: 1360-1363

9. Shimabukuro M, Koyama K, Chen G et al. (1997) Direct antidiabetic effect of leptin through triglyceride depletion of tissues. Proc Natl Acad Sci USA 94: 4637-4641

10. Hardie L, Trayhurn P, Abramovich D, Fowler P (1997) Circulating leptin in women: a longitudinal study in the menstrual cycle and during pregnancy. Clin Endocrinol 47: 101-106

11. Ostlund RE, Yang JW, Klein S, Gingerich R (1996) Relation between plasma leptin concentration and body fat, gender, diet, age, and metabolic covariates. J Clin Endocrinol Metab 81: 3909-3913

12. Schrauwen P, van Marken Lichtenbelt W, Westerterp K, Saris W (1997) Effect of diet composition on leptin concentration in lean subjects. Metabolism 46: 420-424

13. Havel P, Kasim-Karakas S, Mueller W, Johnson P, Gingerich R, Stern J (1996) Relationship of plasma leptin to plasma insulin and adiposity in normal weight and overweight women: effects of dietary fat content and sustained weight loss. J Clin Endocrinol Metab 81: 4406-4413

14. Maffei M, Halaas J, Ravussin E et al. (1995) Leptin levels in human and rodents measurement of plasma leptin and ob RNA in obese and weigh-reduced subjects. Nature Med 1: 1155-1161
15. Considine R, Sinha M, Heiman M et al. (1996) Serum immunoreactive-leptin concentrations in normal-weight and obese humans. N Engl J Med 334: 292-295

16. Mantzoros CS, Moschos SJ (1998) Leptin: in search of role(s) in human physiology and pathophysiology. Clin Endocrinol 49: 551-567

17. Friedman JM, Halaas JL (1998) Leptin and the regulation of body weight in mammals. Nature 395: 763-770

18. Considine RV (1997) Weight regulation, leptin and growth hormone. Horm Res 48: 116-121

19. Bray GA, York DA (1997) Leptin and clinical medicine: a new piece in the puzzle of obesity. J Clin Endocrinol Metab 82: 2771-2776

20. Harrold JA, Cai X, Williams G (1998) Leptin, the hypothalamus and the regulation of adiposity. Curr Opin Lipidol 9: 295-299

21. Girard J (1997) Is leptin the link between obesity and insulin resistance? Diabetes Metab 23: 16-24

22. Woods SC, Seeley RJ, Porte D, Schwartz MW (1998) Signals that regulate food intake and energy homeostasis. Science 280: 1378-1383

23. Boden G, Chen X, Mozzoli M, Ryan I (1996) Effect of fasting on serum leptin in normal human subjects. J Clin Endocrinol Metab 81: 3419-3423

24. Weigle DS, Duell PB, Connor WE, Steiner RA, Soules MR, Kuijper JL (1997) Effect of fasting, refeeding, and dietary fat restriction on plasma leptin levels. J Clin Endocrinol Metab 82: 561-565

25. Grinspoon SK, Askari H, Landt ML et al. (1997) Effects of fasting and glucose infusion on basal and overnight leptin concentrations in normal-weight women. Am J Clin Nutr 66: 1352-1356

26. Rosenbaum M, Nicolson M, Hirsch J, Murphy E, Chu F, Leibel RL (1997) Effects of weight change on plasma leptin concentrations and energy expenditure. J Clin Endocrinol Metab 82: 3647-3654

27. Duell PB, Weigle DS, Conner WE (1998) Effects of energy intake on the regulation of plasma leptin concentrations. Am J Clin Nutr 68: 1304

28. Dubuc GR, Phinney SD, Stern JS, Havel PJ (1998) Changes of serum leptin and endocrine and metaboic parameters after 7 days energy restriction in men and women. Metabolism 47: 429-434

29. Andersen PH, Kristensen K, Pedersen SB, Hjollund E, Schmitz O, Richelsen B (1997) Effects of long-term total fasting and insulin on ob gene expression in obese patients. Eur J Endocrinol 137: 229-233

30. Vidal H, Auboeuf D, De Vos P et al. (1996) The expression of ob gene is not acutely regulated by insulin and fasting in human abdominal subcutaneous adipose tissue. J Clin Invest 98: 251-255

31. Kolaczynski JW, Considine RV, Ohannesian J et al. (1996) Responses of leptin to short-term fasting and refeeding in humans. A link with ketogenesis but not ketones themselves. Diabetes 45: 1511-1515

32. Hennes MM, Dua A, Maas DL, Sonnenberg GE, Krakower GR, Kissebah AH (1997) Relationships of plasma leptin levels to changes in plasma free fatty acids in women who are lean and women who are abdominally obese. Obes Res 5: 442-446

33. Boden G, Chen X, Kolaczynski JW, Polansky M (1997) Effects of prolonged hyperinsulinemia on serum leptin in normal human subjects. J Clin Invest 100: 1107-1113

34. Kolaczynski JW, Ohannesian JP, Considine RV, Marco CC, Caro JF (1996) Responses of leptin to short-term and prolonged overfeeding in humans. J Clin Invest 81: $4162-4165$ 
35. Lin X, Chavez MR, Bruch RC et al. (1998) The effects of a high fat diet on leptin mRNA, serum leptin and the response to leptin are not altered in a rat strain susceptible to high fat diet-induced obesity. J Nutr 128: 1606-1613

36. Surwit RS, Petro AE, Parekh P, Collins S (1997) Low plasma leptin in response to dietary fat in diabetes- and obesity-prone mice. Diabetes 46: 1516-1520

37. Rousseau V, Becker DJ, Ongemba LN, Rahier J, Henquin JC, Brichard SM (1997) Developmental and nutritional changes of ob and PPAR gamma 2 gene expression in rat white adipose tissue. Biochem J 321: 451-456

38. Boado RJ, Golden PL, Levin N, Pardridge WM (1998) Upregulation of blood-brain barrier short-form leptin receptor gene products in rats fed a high fat diet. J Neurochem 71: 1761-1764

39. Havel PJ, Townsend R, Chaump L, Teff K (1999) High fat meals reduce 24 hour circulating leptin concentrations in women. Diabetes 48: 334-441

40. Drewes C, Nauck MA, Horn R, Holst J, Schmiegel W, Brabant G (1997) A liquid mixed meal or exogenous glucagon-like peptide 1 (GLP-1) do not alter plasma leptin concentrations in healthy volunteers. Acta Diabetol 34: 230-234

41. Heini AF, Lara-Castro C, Schneider H, Kirk KA, Considine RV, Weinsier RL (1998) Effect of hydrolyzed guar fiber on fasting and postprandial satiety and satiety hormones: a double-blind, placebo-controlled trial during controlled weight. J Obes Rel Metab Disord 22: 906-909

42. Mantzoros CS, Prasad AS, Beck FW et al. (1998) Zinc may regulate serum leptin concentrations in humans. J Am Coll Nutr 17: 270-275

43. Joannic JL, Oppert JM, Lahlou N et al. (1998) Plasma leptin and hunger ratings in healthy humans. Appetite 30: $129-138$

44. Herrmann TS, Bean ML, Black TM, Wang P, Coleman RA (1999) High-glycemic index carbohydrate diet alters the diurnal rhythm of leptin but not insulin concentrations in healthy adults. Submitted to: Am J Clin Nutr

45. Korbonits M, Trainer PJ, Little JA et al. (1997) Leptin levels do not change acutely with food administration in normal or obese subjects, but are negatively correlated with pituitary-adrenal activity. Clin Endocrinol 46: 751-757

46. Lepercq J, Cauzac M, Lahlou N et al. (1998) Overexpression of placental leptin in diabetic pregnancy: a critical role for insulin. Diabetes 47: 847-850

47. Kolaczynski JW, Nyce MR, Considine RV et al. (1996) Acute and chronic effects of insulin on leptin production in humans: studies in vivo and in vitro. Diabetes 45: 699-701

48. Tuominen JA, Ebeling P, Stenman UH, Heiman ML, Stephens TW, Koivisto VA (1997) Leptin synthesis is resistant to acute effects of insulin in insulin-dependent diabetes mellitus patients. J Clin Endocrinol Metab 82: 381-382

49. Saad MF, Khan A, Sharma A et al. (1998) Physiological insulinemia acutely modulates plasma leptin. Diabetes 47: 544-549

50. Utriainen T, Malmstrom R, Makimattila S, Yki-Järvinen H (1996) Supraphysiological hyperinsulinemia increases plasma leptin concentrations after $4 \mathrm{~h}$ in normal subjects. Diabetes 45: 1364-1366

51. Muscelli E, Camastra S, Masoni A et al. (1996) Acute insulin administration does not affect plasma leptin levels in lean or obese subjects. Eur J Clin Invest 26: 940-943

52. Malmstrom R, Taskinen MR, Karonen SL, Yki-Järvinen H (1996) Insulin increases plasma leptin concentrations in normal subjects and patients with NIDDM. Diabetologia 39: 993-996
53. Heimburger O, Lonnqvist F, Danielsson A, Nordenstrom J, Stenvinkel P (1997) Serum immunoreactive leptin concentration and its relation to the body fat content in chronic renal failure. J Am Soc Nephrol 8: 1423-1430

54. Daschner M, Tonshoff B, Blum WF et al. (1998) Inappropriate elevation of serum leptin levels in children with chronic renal failure. European Study Group for Nutritional Treatment of Chronic Renal Failure in Childhood. J Am Soc Nephrol 9: 1074-1079

55. Merabet E, Dagogo-Jack S, Coyne DW et al. (1997) Increased plasma leptin concentration in end-stage renal disease. J Clin Invest 82: 847-850

56. Halleux CM, Servais I, Reul BA, Detry R, Brichard SM (1998) Multihormonal control of ob gene expression and leptin secretion from cultured human visceral adipose tissue: increased responsiveness to glucocorticoids in obesity. J Clin Endocrinol Metab 83: 902-910

57. Wabitsch M, Jensen PB, Blum WF et al. (1996) Insulin and cortisol promote leptin production in cultured human fat cells. Diabetes 45: 1435-1438

58. Havel PJ, Uriu-Hare JY, Liu T, Stanhope KL, Stern JS, Keen CL (1998) Marked and rapid decreases of circulting leptin in streptozotocin diabetic rats: reversal by insulin. Am J Physiol 274: R1482-R1491

59. Mueller WM, Gregoire F, Stanhope KL et al. (1998) Evidence that glucose metabolism regulates leptin secretion from cultured adipocytes. Endocrinology 139: 551-558

60. Wang J, Liu R, Hawkins M, Barzilai N, Rosseti L (1998) A nutrient-sensing pathway regulates leptin gene expression in muscle and fat. Nature 393: 684-688

61. Hresko RC, Heimberg H, Chi MMY, Mueckler M (1998) Glucosamine-induced insulin resistance in 3T3-L1 adipocytes is caused by depletion of intracellular ATP. J Biol Chem 273: 20658-20668

62. Fehmann HC, Peiser C, Bode HP et al. (1997) Leptin: a potent inhibitor of insulin secretion. Peptides 18: 1267-1273

63. Fehmann HC, Berghofer P, Brandhorst D et al. (1997) Leptin inhibition of insulin secretion from isolated human islets. Acta Diabetol 34: 249-252

64. Leclercq-Meyer V, Malaisse WJ (1998) Failure of human and mouse leptin to affect insulin, glucagon and somatostatin secretion by the perfused rat pancreas at physiological glucose concentration. Mol Cell Endocrinol 141: 111-118

65. Emilsson V, Liu YL, Cawthorne MA, Morton NM, Davenport M (1997) Expression of the functional leptin receptor mRNA in pancreatic islets and direct inhibitory action of leptin on insulin secretion. Diabetes 46: 313-316

66. Harvey J, McKenna F, Herson PS, Spanswick D, Ashford ML (1997) Leptin activates ATP-sensitive potassium channels in the rat insulin-secreting cell line, CRI-G1. J Physiol 504: 527-535

67. Kieffer TJ, Heller RS, Leech CA, Holz GG, Habener JF (1997) Leptin suppression of insulin secretion by the activation of ATP-sensitive $\mathrm{K}+$ channels in pancreatic betacells. Diabetes 46: 1087-1093

68. Sinha MK, Ohannesian JP, Heiman ML et al. (1996) Nocturnal rise of leptin in lean, obese, and non-insulin dependent diabetes mellitus subjects. J Clin Invest 97: 1344-1347

69. Matkovic V, Ilich JZ, Badenhop NE et al. (1997) Gain in body fat is inversely related to the nocturnal rise in serum leptin level in young females. J Clin Endocrinol Metab 82: 1368-1372

70. Licinio J, Negrao AB, Mantzoros C et al. (1998) Sex differences in circulating human leptin pulse amplitude: clinical implications. J Clin Endocrinol Metab 83: 4140-4147 
71. Langendonk JG, Pijl H, Toornvliet AC et al. (1998) Circadian rhythm of plasma leptin levels in upper and lower body obese women: influence of body fat distribution and weight loss. J Clin Endocrinol Metab 83: 1706-1712

72. Laughlin GA, Yen SS (1997) Hypoleptinemia in women athletes: absence of a diurnal rhythm with amenorrhea. J Clin Endocrinol Metab 82: 318-321

73. Stoving RK, Vinten J, Handberg A et al. (1998) Diurnal variation of the serum leptin concentration in patients with anorexia nervosa. Clin Endocrinol 48: 761-768

74. Kousta E, Chrisoulidou A, Lawrence NJ, al-Shoumer KA, Parker KH, McCarthy MI, Johnston DG (1998) The circadian rhythm of leptin is preserved in growth hormone deficient hypopituitary adults. Clin Endocrinol 48: 685-690

75. Balligand JL, Brichard SM, Brichard V, Desager JP, Lambert M (1998) Hypoleptinemia in patients with anorexia nervosa: loss of circadian rhythm and unresponsiveness to short-term refeeding. Eur J Endocrinol 138: 415-420
76. Saad MF, Riad-Gabriel MG, Khan A et al. (1998) Diurnal and ultradian rhythmicity of plasma leptin: effects of gender and adiposity. J Clin Endocrinol Metab 83: 453-459

77. Sinha MK, Sturis J, Ohannesian J et al. (1996) Ultradian oscillations of leptin secretion in humans. Biochem Biophys Res Comm 228: 733-738

78. Saladin R, De Vos P, Guerre-Millo M et al. (1995) Transient increase in obese gene expression after food intake or insulin administration. Nature 377: 527-529

79. Stehling O, Doring H, Ertl J, Preibisch G, Schmidt I (1996) Leptin reduces juvenile fat stores by altering the circadian cycle of energy expenditure. Am J Physiol 271: R1770-R1774

80. Schoeller DA, Cella LK, Sinha MK, Caro JF (1997) Entrainment of the diurnal rhythm of plasma leptin to meal timing. J Clin Invest 100: 1882-1887 